\title{
Agreement among bacteriological findings, vaginal discharges, and endometrial cytology for endometritis detection in postpartum beef cows
}

\author{
N. Salah ${ }^{1,2}$, N. Yimer ${ }^{1 *}$, H. Wahid ${ }^{1}$, Y. Rosnina ${ }^{1}$, B. Siti khairani3, M.A. Omar ${ }^{4}$ \\ ${ }^{1}$ Department of Veterinary Clinical Studies, Faculty of Veterinary Medicine, Universiti Putra Malaysia, UPM 43400 Serdang, Selangor, \\ Malaysia, ${ }^{2}$ Department of Obstetrics and Surgery, Faculty of Veterinary Medicine, University Of Diyala, Baquba, Iraq, ${ }^{3}$ Department of \\ Veterinary Pre-clinical Studies, Universiti Putra Malaysia, UPM 43400 Serdang, Selangor, Malaysia, ${ }^{4}$ Department of Para- clinical Studies, \\ Faculty of Veterinary Medicine, Universiti Putra Malaysia, UPM 43400 Serdang, Selangor, Malaysia,
}

\section{A B S T R A C T}

\begin{abstract}
Aim of the study: This study aims to demonstrate the relationship among vaginal secretions, bacterial isolates, and endometrial cytology during 20-30 days postpartum in beef cows. Background: Endometritis is one of the most common diseases that occurs in dairy cow after several weeks postpartum period. There is two types of endometritis, clinical and subclinical endometritis that cause severe economic losses by increased days open, calving interval and numbers of services to conception. Materials and Methods: A total of 82 beef cows, aged 3 years to 7 years and at 20-30 days post-calving, were enrolled in this study. All the cows were checked by transrectal palpation, ultrasound, and vaginal secretions collection. A four-grade system $(0=$ clear mucus, $1=$ mucus containing flecks of pus, 2 = discharge including $<50 \%$ pus, and $3=$ involving $>50 \%$ pus) was used to categorize vaginal secretions of these cows. Endometrial cytology and bacteriological samples were then collected using a cytobrush technique. Results: Nine of 82 beef cows $(11 \%)$ had abnormal vaginal secretions (grade 1-3) and indicated to clinical endometritis (CE), and nine of 73 clinically healthy cows (12.32\%) had subclinical endometritis (SCE, $\geq 8 \%$ PMN cows). The agreement among endometrial examination, polymorphonuclear neutrophil percentage (PMN \%), and vaginal discharge score $(0-3)$ was moderate $(k=0.48, p<0.01)$, whereas that between vaginal discharge score $(0-3)$ and bacteriological finding was poor $(k=0.032, p=0.51)$. The agreement between bacterial finding and PMN \% was also poor $(\mathrm{k}=0.15, \mathrm{p}=0.02)$. Escherichia coli was the most common bacteria isolated from healthy (14.6 \%), CE $(38.8 \%)$, and SCE $(42.8 \%)$ cows. Moreover, E. coli was the major bacteriological risk factor for SCE occurrence. E. coli and Staphylococcus aureus were the most common risk factors for the occurrence of CE. Conclusion: A moderate agreement exists among $\mathrm{PMN} \%$, bacteriological findings, and vaginal secretions, whereas a poor agreement exists between bacterial findings and PMN \%. $E$. coli, S. aureus, and dystocia were the major factors affecting uterine infection in beef cows. CE and SCE insignificantly affected the reproductive performance of beef cows.
\end{abstract}

Keywords: Beef cows; Endometrial cytology; Endometritis; Postpartum uterus; Risk factors

\section{INTRODUCTION}

All postpartum cows suffer from pathogenic microorganism contamination of the uterus 2 weeks to 3 weeks after parturition, and more than $80 \%$ of the cows after calving are exposed to uterine contamination by Escherichia coli, Fusobacterium sp., Arcanobacterium pyogenes, Streptococcus sp., Staphylococcus sp., Clostridium sp., Pasteurella multocida, and Bacteroides sp (Sheldon et al., 2006). McDougall et al. (2011) isolated and registered more than 35 bacteria species that increased the risk for genital tract infection after parturition in cows.
Uterine infection can be categorized into puerperal metritis, clinical metritis, clinical endometritis, and subclinical endometritis (Sheldon et al., 2006). Clinical endometritis (CE) is known as endometrial inflammation with purulent or mucopurulent discharge; this disease can be detected 21 days after calving and is not associated with clinical signs of sickness (Sheldon et al., 2006). The correct diagnosis of $\mathrm{CE}$ depends on the presence of vaginal discharge (LeBlanc et al., 2002). CE can be diagnosed using a vaginoscope, meter check device, or gloved hand (Leutert et al., 2012). The term "purulent vaginal discharge" has been adopted for use as instead of term CE because the

\footnotetext{
${ }^{*}$ Corresponding author:

N. Yimer, Faculty of Veterinary Medicine, Universiti Putra Malaysia, UPM 43400 Serdang, Selangor, Malaysia.

E-mail: nurhusien@upm.edu.my

Received: 03 November 2016;

Revised: 20 January 2017;

Accepted: 23 January 2017;

Published Online: 29 January 2017
} 
presence of abnormal genital discharge does not necessarily indicate endometrial inflammation (Dubuc et al., 2010). Subclinical endometritis (SCE) is known as the endometrial inflammation of the uterus without mucopurulent material accumulation in the vagina (Sheldon et al., 2006). SCE has also been identified as cytological endometritis (Gilbert et al., 2005). Dubuc et al. (2010) described cytological endometritis as an elevated ratio of polymorphonuclear neutrophils (PMN) in endometrial cytology samples obtained by cytobrush or low-volume uterine lavage. Assessment of cows suffering from endometrial infections is hampered by the lack of consensus on an acceptable definition of endometritis in cows (Gilbert et al., 2005; Sheldon et al., 2006) and simple, effective diagnostic methods. Despite that transrectal palpation of the uterus is commonly used to diagnose endometritis, diagnosis, this technique cannot accurately identify cows with endometritis and subsequent reduced fertility (Runciman et al., 2008).

SCE can be detected using several methods, some of which can be performed during collection of endometrial cells. In these techniques, endometrial and inflammatory cells may be collected using a guarded cotton swab (Studer and Morrow, 1978), uterine biopsy (Bourke et al., 1997), uterine lavage (Gilbert et al., 2005), or cytobrush (Kasimanickam et al., 2004). However, the significant challenge in SCE diagnosis is the absence of consensus among studies regarding the sampling time and cutoff values to differentiate diseased from healthy cows. Scholars have suggested many threshold values for the proportion of PMN, ranging from $10 \%$ to $18 \%$ (Kasimanickam et al., 2004).

The occurrence of uterine diseases in beef cows in Malaysia remains unclear, and the relationship between bacterial contamination and rate of postpartum uterine diseases has been rarely investigated. The present study aims to assess the relationship among bacterial contamination, vaginal discharges, and endometrial cytology findings in postpartum beef cows and to determine the diagnostic value of these parameters for detection of CE and SCE.

\section{MATERIALS AND METHODS}

This study was approved by the Institutional Animal Care and Use Committee, Universiti Putra Malaysia (Ref. UPM/ IACUC/AUP-R099/2015; 10 February 2016)

One hundred cows (55 Brangus and 45 Kedah-Kelantan breeds) at 20 days to 30 days post-calving period were obtained from three different private beef farms and all samples were collected from animals while cows remained at their farm of origin between June 2015 to October
2016. The beef farms are located in Serdang, Selangor where the temperature is $28{ }^{\circ} \mathrm{C}$, and relative humidity is about $70 \%$. The cows were aged $3-7$ years, weighed $300-450 \mathrm{~kg}$, and managed under free grazing. The cows were also fed according to field management after providing concentrated feed, which consisted of alfalfa, corn silage, beet pulp, cottonseed, soybean, corn, and barley. Individual animal data on calving history, lactation, breed, parity, and so on were recorded. The farms used many bulls with a high fertility and passed a breeding soundness examination every two month and these farms used 20-1 as cow-to-bull ratio for natural mating after the postpartum period. The body condition score (BCS) of the cows was evaluated by using a 5-point scale (Ferguson et al., 1994). Pregnancy diagnosis for cows was achieved by using ultrasound technique at 150 and 200 days after calving.

\section{Examination of cows}

All cows were checked by rectal palpation 20 to 30 days after calving to evaluate degree of uterine involution, symmetry of uterine horns, and position of the uterus relative to the pelvic rim. Genital tract discharge of all cows was checked through examination of vaginal secretions by using hands covered with clean disposable long gloves at 20 days to 30 days post-calving to identify CE cases. A fourgrade system $(0=$ clear mucus, $1=$ mucus containing flecks of pus, $2=$ discharge including $<50 \%$ pus, and $3=$ involving $>50 \%$ pus) was used to categorize vaginal secretions (Williams et al., 2005). The vulva and perineum region were washed, cleaned, sterilized with iodine, and dried using clean, sterile paper towels. The area was then lubricated (Triad Sterile Lubricating Jelly, H\&P Industries Inc., Mukwonago, WI, USA). The hand covered with a long sterile disposable glove was inserted into the vagina far enough to allow observation of the nature of the fluid; if necessary, a light source was used to obtain evidence of abnormal cervical secretion (Barlund et al., 2008).

\section{Endometrial cytology using cytobrush method}

Endometrial cytological samples were collected from cows by using a modified sterile Cytobrush Plus GT (Medscand Medical, Germany) (Madoz et al., 2013). The handle was shortened to $2 \mathrm{~cm}$ and made thread-like to enable insertion into a stainless steel rod (artificial insemination AI gun $65 \mathrm{~cm}$ in length, $4 \mathrm{~mm}$ outside diameter). The cytobrush and stainless steel rod combination were protected by a plastic sheath (Chemise Sanitaire, IMV Technologies, France) to avoid vaginal contamination, lubricated (Triad Sterile Lubricating Jelly, H\&P Industries Inc., Mukwonago, WI, USA), and introduced into the vagina. A sleeved arm was introduced into the rectum to facilitate passage of instruments through the genital tract and os cervix. When the instrument reaches the uterus, the cytobrush was exposed and turned many times to 
collect cellular material from the adjacent endometrium. The cytobrush was again protected by the plastic sheath and withdrawn from the genital tract. The sample was rolled on the sterile microscopic slide $(75 \mathrm{~mm} \times 25 \mathrm{~mm})$ and stored in a transport medium (LABCHEM SDN.BHD) for bacteriological analysis. All slides were fixed with methanol for $30 \mathrm{~min}$, transported to the laboratory within 3 hours, stained with $5 \%$ Giemsa stain for $3 \mathrm{~min}$, and dried. All of the slides were evaluated by counting 300 cells at 400× magnification (Leitz Labourlux-S, Wetzlar, Germany) to determine the percentage of neutrophils (PMN \%). Endometrial threshold value $\geq 8 \%$ was used to determine the SCE occurrence in the farms between 20 and 30 days postpartum (Madoz et al., 2013).

\section{Bacteriological samples}

Bacteriological samples were transferred into sterile tubes containing thioglycolate broth as transport medium, transported to the laboratory at $4{ }^{\circ} \mathrm{C}$, and immediately processed for bacteriological examination. Samples were cultured aerobically on sheep blood agar, MacConkey agar, and nutrient agar. Bacterial growth on the culture plates was scored semi-quantitatively after $24 \mathrm{~h}$ of incubation at $37^{\circ} \mathrm{C}$ for aerobic growth. Bacteria were identified based on the shape of the bacterial colony, Gram stain, hemolysis, morphology, and tests on coagulase, oxidase, catalase, indole production, and methyl red.

\section{Experimental animals}

One hundred cows enrolled in this study, 18 cows were excluded because of the presence of clinical mastitis ( 5 cows), sold (7 cows), lameness (3 cows) and inadequate endometrial cytological sampling ( 3 cows). The remaining 82 cows were identified as Brangus (54.87\%, 45/82), Kedah-Kelantan $(45.12 \%, 37 / 82)$, primiparous $(29.2 \%$, $24 / 82)$, and multiparous (70.8\%, 58/82). Calving assistance (dystocia), retained placenta, and twins were recorded in $11 \%(9 / 82), 4.8 \%(4 / 82)$, and $2.4 \%(2 / 82)$ of the cows.

\section{Data and statistical analyses}

Clinical findings and all data were recorded and encoded into Excel software (Excel 2007, Microsoft Office Corporation, Redmond, WA, USA). The data included BCS, parity, date of parturition, calving assistance rendered, postpartum diseases, vaginal clinical findings (discharge score), cytological examination findings, bacteriological isolation results, and reproductive performance of cows. All the statistical methods were performed by SPSS software (version 18.0, IBM SPSS Inc., Chicago: USA) and Excel 2007. The occurrence of SCE and CE was determined based on clinical examination results, vaginal discharges, and endometrial cytological samples. The agreement among vaginal discharge grades, the percentage of PMN, and bacteriological findings were examined using
Kappa analyses (Santos et al., 2009). Chi-square analysis was used to compare the bacteriological results of healthy and infected cows. Moreover, the relative risk factor for the occurrence of SCE and CE was measured, considering isolated bacteria (E. coli, Staphylococcus, and Bacillus) consequently, just isolated bacteria with $\mathrm{P}$ value $<0.10$ were considered to have significant effects and included in regression model. A binary logistic regression model was used to analyze factors for the occurrence of SCE and CE. These factors included infection with E. coli $(0=$ no infection, $1=$ infection $)$, infection with Bacillus spp. $(0=$ no infection, $1=$ infection $)$, infection with Staphylococcus spp. $(0=$ no infection, $1=$ infection $)$, calving $(0=$ normal, $1=$ dystocia $)$, and BCS $(0=\geq 3,1=>3)$, parity $(0=$ primiparous, $1=$ multiparous $)$.

Reproductive performance parameters were reported by calculating the percentage of pregnancy rate at 150 and 200 days postpartum by using ultrasound technique. A Cox regression model for non-pregnancy within 200 days postcalving was established using the following grading system: $\mathrm{CE}(0=\mathrm{CE}, 1=$ no $\mathrm{CE})$, SCE $(0=\mathrm{SCE}, 1=$ no SCE $)$, infection with $E$. coli $(0=$ no infection, $1=$ infection $)$, infection with Bacillus spp. ( 0 = no infection, $1=$ infection $)$, infection with Staphylococcus spp. $(0=$ no infection, $1=$ infection $)$, calving $(0=$ normal, $1=$ dystocia $)$, and BCS $(0=>3,1=>3$ ) (Madoz et al., 2013). The level of significance was set at 0.05 for all statistical analyses, and the $\mathrm{CI}$ was set at $95 \%$

\section{RESULTS}

\section{Vaginal examination}

Vaginal examination on postpartum days 20-30 showed nine cows $(11 \%)$ with abnormal vaginal secretions. Four cows had a vaginal secretion score of 1 , four cows were scored 2, and one cow was scored 3.

\section{Bacterial isolation}

Regarding bacterial isolates, twenty different microorganisms were identified among the 114 bacterial isolates obtained from 56 of the $82(68 \%)$ postpartum cows; no bacterial isolates were obtained from the remaining 26 cows. Multiple bacterial species were isolated from 38 of the 56 cows $(68 \%)$, whereas a single bacterial species was isolated from the remaining 18 cows. Bacterial isolates are shown in Table 1. E. coli, Bacillus sp., Staphylococcus sp., and Streptococcus sp. accounted for $21.9 \%(25 / 114), 12.28 \%$ $(14 / 114), 6.14 \%(7 / 114)$, and $13.15 \%(15 / 114)$ of the bacteria species isolated, respectively (Table 1). E. coli was the most isolated bacteria from SCE $(42.85 \% ; 6 / 14)$, and CE cows $(38.88 \% ; 7 / 18)$, which was significantly higher $(p>0.05)$ than in healthy cows $(14.6 \% ; 12 / 82)$. 
Table 1: Percentage of isolated bacteria in healthy, CE, and SCE cows

\begin{tabular}{|c|c|c|c|}
\hline $\begin{array}{l}\text { Species of bacteria } \\
\text { isolated }\end{array}$ & $\begin{array}{l}\text { Healthy } \\
\text { cows } 82 \\
\text { isolated } \\
\text { bact }(\%) \\
\end{array}$ & $\begin{array}{c}\text { CE* cows } \\
18 \text { isolated } \\
\text { bact }(\%)\end{array}$ & $\begin{array}{c}\text { SCE }^{* *} \text { cows } \\
14 \text { isolated } \\
\text { bact }(\%)\end{array}$ \\
\hline Escherichia coli & $12(14.63)^{a}$ & $7(38.88)^{b}$ & $6(42.85)^{b}$ \\
\hline Bacillus spp. & $10(12.19)$ & $2(11.11)$ & $2(14.28)$ \\
\hline $\begin{array}{l}\text { Staphylococcus } \\
\text { schleiferi }\end{array}$ & $2(2.43)$ & & $1(7.14)$ \\
\hline Staphylococcus aureus & $1(1.21)^{c}$ & $4(22.22)^{d}$ & \\
\hline Streptococcus bovis & $3(3.65)$ & $1(5.5)$ & $1(7.14)$ \\
\hline $\begin{array}{l}\text { Streptococcus } \\
\text { pneumonia }\end{array}$ & $4(4.87)$ & - & $1(7.14)$ \\
\hline $\begin{array}{l}\text { Streptococcus } \\
\text { agalactia }\end{array}$ & $2(2.43)$ & - & - \\
\hline $\begin{array}{l}\text { Streptococcus } \\
\text { zooepidemicus }\end{array}$ & $3(3.65)$ & & - \\
\hline A. pyogenes & $1(1.21)$ & $1(5.5)$ & - \\
\hline Proteus spp. & $1(5.5)$ & $1(5.5)$ & - \\
\hline Enterobact faecium & $4(4.87)$ & $1(5.5)$ & - \\
\hline Alcaligenes faecalis & $5(6.09)$ & - & - \\
\hline Enterobacter cloacae & $5(6.09)$ & - & $1(7.14)$ \\
\hline Klebsiella pneumoniae & $3(3.65)$ & $1(5.5)$ & $1(7.14)$ \\
\hline $\begin{array}{l}\text { Acinetobacter } \\
\text { baumannii }\end{array}$ & $4(4.87)$ & - & $1(7.14)$ \\
\hline Acinetobacter Iwoffii & $4(4.87)$ & - & - \\
\hline $\begin{array}{l}\text { Acinetobacte } \\
\text { rcalcoaceticus }\end{array}$ & $5(6.09)$ & - & - \\
\hline Chromobacterium & $4(4.87)$ & - & - \\
\hline Pantoea agglomerans & $4(4.87)$ & - & - \\
\hline Pasteurella spp. & $2(2.43)$ & - & - \\
\hline $\begin{array}{l}\text { Total bacterial } \\
\text { isolation }\end{array}$ & $82(100)$ & $18(100)$ & $14(100)$ \\
\hline
\end{tabular}

The commonly isolated bacteria from CE cows were E. coli (38.88\%), Staphylococcus aureus (22.2\%), Bacillus sp. (11.11\%), Streptococcus bovis (5.5\%), Proteus sp. (5.5.1\%), and $A$. pyogenes (5.5. \%). Staphylococcus aureus percentage was higher $(\mathrm{p}>0.05)$ in CE $(22.2 \%)$ than in healthy cows $(1.21 \%)$. The most common bacterial species present in SCE cows were E. coli (42.85\%) and Bacillus sp. (14.2\%). Moreover, no bacteria were isolated from two cows (2/9) with SCE.

\section{Endometrial cytology}

All cows were sampled by cytobrush, of which, nine cows manifested SCE $(12.3 \%$, determined using $\geq 8 \%$ PMN as threshold value and vaginal discharge score $=0$ ). The average PMN $\%$ on the slides ranged from 0 to $29 \%$. The agreement among endometrial examination, number of PMN (\%), and vaginal discharge score (0-3) was moderate $(\mathrm{k}=0.48, \mathrm{p}=>0.01$; Table 2$)$. There is a poor agreement between vaginal discharge score (0-3) and bacteriological finding $(\mathrm{k}=0.032, \mathrm{p}=0.51)$ and between bacterial finding and PMN $(\mathrm{k}=0.15, \mathrm{p}=0.02)$ (Table 2).
Table 2: Beef cows with $<8 \%$ and $\geq 8 \%$ of polymorphonuclear leukocytes (PMN) in endometrial cytology samples, negative (score $\mathbf{0}$ ) or positive (scores 1,2 , and 3 ) gross vaginal inflammation score, and the presence or absence of bacterial contamination at days $20-30$ post calving the Kappa statistic $(K)$ is a measure of the level of agreement between the tests, where $1=$ complete agreement and $0=$ no agreement

\begin{tabular}{|c|c|c|c|}
\hline & \multicolumn{2}{|c|}{ Bacterial isolation } & \multirow[t]{2}{*}{ Kappa } \\
\hline & Positive & Negative & \\
\hline \multicolumn{4}{|l|}{ Cytobrush } \\
\hline$\geq 8 \% \mathrm{PMN}$ & 16 & 2 & $K=0.15$ \\
\hline \multirow[t]{3}{*}{$>8 \% \mathrm{PMN}$} & 40 & 24 & $P=0.028$ \\
\hline & \multicolumn{2}{|c|}{ Vaginal discharges } & \\
\hline & Positive & Negative & \\
\hline \multicolumn{4}{|c|}{ Bacterial isolation } \\
\hline Positive & 7 & 49 & $\mathrm{~K}=0.032$ \\
\hline \multirow[t]{3}{*}{ Negative } & 2 & 24 & $P=0.51$ \\
\hline & \multicolumn{2}{|c|}{ Vaginal discharges } & \\
\hline & Positive & Positive & \\
\hline \multicolumn{4}{|l|}{ Cytobrush } \\
\hline$\geq 8 \% \mathrm{PMN}$ & 7 & 9 & $\mathrm{~K}=0.48$ \\
\hline$>8 \% \mathrm{PMN}$ & 2 & 64 & $P=000$ \\
\hline
\end{tabular}

Risk factors affecting the occurrence of CE and SCE $E$. coli was the major bacteriological risk factor for the occurrence of SCE (odds ratio $(\mathrm{OR})=8.6 ; 95 \%$ $\mathrm{CL}=1.89-39.68 ; \mathrm{P}=0.03)$ and $\mathrm{CE}(\mathrm{OR}=7 ; 95 \%$ $\mathrm{CL}=1.05-47.1 ; \mathrm{P}=0.04$ ) (Table 2 and 3). Staphylococcus aureus was the major bacteriological risk factor for the occurrence of CE (OR $=10.16$; 95\% CL $=1.66-61.91$; $\mathrm{p}=0.01)$. Dystocia was considered a risk factor for CE occurrence in beef cows (OR $=10.6 ; 95 \% \mathrm{CL}=1.48-76.09$; $\mathrm{p}=0.02)$, whereas BSC was a risk factor only for SCE occurrence $(\mathrm{OR}=11.7 ; 95 \% \mathrm{CL}=1.24-113.32 ; \mathrm{p}=0.01)$. Other isolated bacterial species and parity did not have obvious risk effects on the occurrence of $\mathrm{CE}$ and SCE (Table 3 and 4).

\section{Reproductive performance}

Cox regression model analysis showed that SCE, CE, factors, and bacterial agents did not significantly affect the risk for non-pregnancy at 200 days after calving (Table 5). The pregnancy rates at 150 and 200 days postpartum were $35.3 \%(29 / 82)$ and $45.12 \%(37 / 82)$, respectively. The percentages of pregnant cows at 150 days postpartum were $37.5 \%$ (24/64), $33.3 \%(3 / 9)$, and $22.2 \%(2 / 9)$ in healthy, SCE, and CE groups, respectively. The percentages of pregnant cows at 200 days postpartum were $46.8 \%$ (30/64), $44.4 \%(4 / 9)$, and $33.3 \%(3 / 9)$ in healthy, SCE, and CE groups, respectively (Table 6 ).

\section{DISCUSSION}

Beef cows consider a primary source of cattle for the meat industry and many problems are affecting the productivity 
Table 3: Bacteriologic relative risk factors for cows diagnoses with clinical endometritis and subclinical endometritis between $\mathbf{2 0}$ and $\mathbf{3 0}$ days postpartum

\begin{tabular}{lccc}
\hline Factor & Relative risk & $\mathbf{9 5 \%} \mathrm{Cl}$ & P value \\
\hline Diagnosis CE* & & & \\
Bacillus & 1.3 & $0.314-5.73$ & 0.64 \\
E coli & 9.9 & $1.33-26.66$ & 0.007 \\
Streptococcus sp. & 2.1 & $0.35-13.08$ & 0.43 \\
Staphylococcus aureus & 8.9 & $3.2-24.6$ & 0.01 \\
Trueperella pyogenes & 4.4 & $0.959-20.53$ & 0.11 \\
Diagnosis SCE & & & \\
E coli & 6.1 & $1.70-21.97$ & 0.002 \\
Bacillus & 1.4 & $0.34-6.15$ & 0.61 \\
Streptococcus sp. & 1.2 & $0.28-5.08$ & 0.80 \\
\hline
\end{tabular}

${ }^{*} \mathrm{CE}$ : Clinical endometritis, ${ }^{* *} \mathrm{SCE}$ : Subclinical endometritis

Table 4: Results of binary logistic regression analysis for the risk of SCE and CE in cows examined at 20 days to 30 days postpartum including calving assistance, body score condition, parity, E. coli infection, and Staphylococcus infection

\begin{tabular}{lccc} 
Variables $^{*}$ & 0dds ratio & $\mathbf{9 5 \%} \mathbf{C l}$ & P value \\
\hline Diagnosis CE & & & \\
E coli & 7.0 & $1.05-47.2$ & 0.04 \\
Staphylococcus aureus & 10.16 & $1.66-61.91$ & 0.01 \\
Parity & 0.69 & $0.154-3.08$ & 0.62 \\
Calving & 10.6 & $1.48-76.09$ & 0.02 \\
BCS & 2.5 & $0.32-19.4$ & 0.37 \\
Diagnosis SCE & & & \\
E coli & 8.6 & $1.89-39.68$ & 0.03 \\
BCS & 11.7 & $1.24-113.32$ & 0.02 \\
Calving assistance & 3.0 & $0.53-16.6$ & 0.21 \\
Parity & 1.93 & $0.56-6.58$ & 0.28 \\
\hline
\end{tabular}

Variables*: CE: clinical endometritis, SCE: Subclinical endometritis, OR: Odds ratio, BCS: body condition score, infection with $E$ coli $(0=$ infection: $1=$ no infection), infection with bacillus ( $0=$ infection: $1=$ no infection), infection with Staphylococcus ( $0=$ infection: $1=$ no infection), calving assistance $(0=$ assisted calving: $1=$ normal calving): $\mathrm{BCS}:(0=>3: 1=\geq 3)$, parity : ( $0=$ primparous: $1=$ multiparous)

Table 5: Results of Cox regression for the hazard of non-pregnancy within 180 days in cows examined 20 days to 30 days after calving

\begin{tabular}{lccc} 
Factors* $^{*}$ & \multicolumn{3}{c}{ No pregnancy } \\
\cline { 2 - 4 } & HR & CL 95\% & P value \\
\hline CE & 1.49 & $0.66-3.34$ & 0.32 \\
SCE & 1.24 & $0.5-2.94$ & 0.61 \\
E coli & 1.3 & $0.63-2.75$ & 0.51 \\
Bacillus & 0.51 & $0.63-2.75$ & 0.44 \\
Staphylococcus & 0.9 & $0.28-2.91$ & 0.86 \\
Calving & 0.51 & $0.26-1.22$ & 0.15 \\
assistance & & & \\
BCS & 0.76 & $0.42-1.37$ & 0.36 \\
\hline
\end{tabular}

*Factors: CE: clinincal CE: clinincal endometritis, SCE, Subclinical endometritis, HR, hazard ratio, BCS: body condition score, CE (0=CE: $1=$ no CE diagnosed), SCE (0=SCE: $1=$ no SCE diagnosed), infection with $E$ coli ( $0=$ infection: $1=$ no infection), infection with bacillus ( $0=$ infection: $1=$ no infection), infection with Staphylococcus ( $0=$ infection: $1=$ no infection), calving assistance ( $0=$ assisted calving: $1=$ normal calving), BCS: $(0=>3: 1=\geq 3)$

of these cows (Diskin and Kenny, 2016). The effects of these factors on $\mathrm{CE}$ and $\mathrm{SCE}$ rates and reproductive performance were also investigated. The overall occurrence of $\mathrm{CE}$ was $11 \%$, which is lower than the range reported by previous studies in cow farms in other countries. Most studies recorded a CE prevalence between $20 \%$ to $40 \%$ in postpartum cows (Heuwieser et al., 2000; McDougall et al., 2011). The discrepancy in the results may be due to decreased post-calving problems, such as dystocia, retained placenta, and metabolic disorders. Furthermore, most cows in this study depended on grazing and had low milk production, thereby developing few stress factors and minimal exposure to uterine infection after calving. The SCE prevalence in the present study was $12.3 \%$, which is lower than that in a previous study in beef cows (Santos et al., 2009) and other studies in dairy cows (Cheong et al., 2011; Madoz et al., 2013). In one of the previous study in beef cows, $17 \%$ of Angus cows (2-78 d postpartum) were positive to endometritis by using low-volume uterine lavage method (Santos et al., 2009).

Thus far, no consensus has been established with regard to the effect of threshold value and time of uterine sampling on SCE diagnosis. SCE can be diagnosed using different cut-off values, such as PMN \% range of 5\%-18, and various techniques using cytobrush and low-volume lavage (Barlund et al., 2008). Other studies depended on the thresholds of PMN \% according to the effects on the reproductive performance (Cheong et al., 2011; McDougall et al., 2011). Kasmanickam et al. (2004) depended on >18\% PMNs as threshold value between 20 -33 days postpartum and $>10 \%$ PMNs between 34 and 47 days postpartum using the cytobrush to diagnosis endometritis while Gilbert et al. (2005) used >5\% PMNs as a significant cutoff point for diagnosis endometritis in cows using lavage method between 40 and 60 days postpartum. The low SCE prevalence may be attributed to differences in geographic area, environment, and endometrial cells counted among the studies. A total of 300 cells were counted per slide in the present study, whereas 100 cells were counted in previous studies (Barlund et al., 2008).

E. coli was the common bacteria isolated from healthy (14.6\%) and endometritic cows $38.8 \%$ in SCE cows and $42.8 \%$ in CE cows) in the period between 20 days to 30 days postpartum; these results are either similar to other studies in the early postpartum interval at cow farms (Santos et al., 2011; Sens and Heuwieser, 2013) or higher than those reported in previous studies (McDougall et al., 2011; Prunner et al., 2014a). Most studies confirmed that E. coli was isolated in the early period of 0 day to 15 days after calving, and the percentage gradually decreased with the advancement of the postpartum period (Werner et al., 2012). The present results agree with previous study demonstrating that $E$. coli and $A$. pyogenes were the common uterine pathogens in the postpartum period (Sens and 
Salah, et al.: Methods for endometritis detection in postpartum beef cows

Table 6: Reproductive performance of early postpartum beef cows subsequent to study of vaginal secretions, endometrial cytology, and bacterial isolations

\begin{tabular}{|c|c|c|c|c|}
\hline Factor & Total (\%) & healthy cows & SCE $^{*}$ & $\mathrm{CE}^{* *}$ \\
\hline Number of cows & 82 & 64 & 9 & 9 \\
\hline $\begin{array}{l}\text { No. of pregnant cows/total, } \\
\text { pregnancy } \% \text { at } 150 \text { days post calving }\end{array}$ & 29/82 ( 35.3$)$ & $24 / 64(37.5)$ & 3/9 (33.3) & $2 / 9(22.2)$ \\
\hline $\begin{array}{l}\text { No. of pregnant cows/total, } \\
\text { pregnancy } \% \text { at } 200 \text { days post calving }\end{array}$ & $37 / 82(45.1)$ & $30 / 64(46.8)$ & $4 / 9(44.4)$ & 3/9 (33.3) \\
\hline
\end{tabular}

* SCE: Subclinical endometritis, ${ }^{* *} \mathrm{CE}$ : Clinical endometritis

Heuwieser, 2013). Werner et al. (2012) reported the lack of association between the abnormal vaginal discharge and E. coli infection in endometritic cows. Although E. coli is a common bacteria in the environment, specific strains of this species have been isolated from cows with uterine diseases (Sheldon et al., 2006). Endometrial pathogenic E. coli is more adherent and invasive in the endometrium compared with E. coli isolated from the uterus of clinically unaffected cows. These pathogenic E. coli strains develop diseases of endometrial surfaces such as postpartum metritis or endometritis in the bovine genital tract (Sheldon et al., 2006). In contrast to most studies, the present study showed a decreased number of $A$. pyogenes (one isolate) in $\mathrm{CE}$ cases, leading to few cases of purulent vaginal discharge (scores 2 and 3) (Zobel, 2013). However, Sens and Heuwieser (2013) reported in the previous study about bacterial isolation during postpartum period that E. Coli and A. pyogenes were the dominant bacteria that isolated from uterus between 7-24 days postpartum.

Moreover, Streptococcus isolation from cows in the present study was less frequent and did not severely affect CE and SCE; similarly, previous studies reported Streptococcus as an opportunistic bacteria in the postpartum uterus (Williams et al., 2005). In contrast to the present findings, Werner et al. (2012) reported that infection with Streptococcus during the early postpartum period increased the risk for the occurrence of abnormal vaginal discharge and elevated uterine PMN \%. In the present study, S. aureus was isolated from CE cows and affected the risk factor for its occurrence. These results are consistent with previous studies, thereby confirming the serious effect of Staphylococcus spp. on uterine infection (Prunner et al., 2014b). However, the results were in contrast to other studies reporting the absence of significant effect of Staphylococcus on CE cows (Williams et al., 2005).

This study showed the effect of calving assistance (dystocia) as a risk factor on CE and SCE; the results are in agreement with previous studies reporting the effect of calving assistance on the rate of possible uterine contamination after calving (Madoz et al., 2013). Rogers et al. (2004) mentioned in one study that cows which had dystocia has more chances to suffer from uterine infections and increased culling rate in the future than those that calved without assistance. However, this result is in contrast with another study that did not find any effect of calving assistance on CE and SCE occurrence (Prunner et al., 2014a).

In the present study, no association was found between BCS and CE occurrence; similarly, previous studies that failed to demonstrate any effect of BCS on CE (Potter et al., 2010). However, Cheong et al. (2011) reported that BSC significantly affected the rate of CE in cows. The present study also demonstrated the effect of BCS on SCE occurrence, which may be attributed to the effect of negative energy balance (NEB) after calving on the immunity of cows, thereby increasing the probability of uterine infection (Gilbert et al., 2005). Hammon et al. (2006) mentioned that uterine infection was accompanied with NEB, which begins before birth and continues through the early lactation; this study also reported that cows with acute NEB exhibit reduced neutrophil function and developed SCE. Body energy reserves at calving consider an essential factor influencing reproductive performance in beef cattle, and it is a most important factor determining when beef heifers and cows will resume cycling after calving and response to postpartum nutrient intake (Wettemann et al., 2003).

In the present study, poor to moderate agreement was found among PMN \%, bacteriological findings, and vaginal discharges; previous results indicated that abnormal discharges do not necessarily indicate uterine infection (Dubuc et al., 2010; Westermann et al., 2010). The present study also showed poor agreement between bacterial findings and PMN, similar to the findings of other studies (Barański et al., 2012). Not all of the bacterial species cause inflammation and infusion of PMN to the uterine endothelium because numerous bacteria may be normal inhabitants of the uterus; uterine infection after calving can also be due to other causes, such as yeast and viruses. Reproductive performance is one of the most common economically important traits in beef production (Bormann et al., 2006).

The current study showed minimal effects of CE, SCE, and isolated bacteria on the reproductive performance of cows because the ability of these cows to self-cured; this finding 
is similar to those reported in a previous study (Prunner et al., 2014b). However, most studies showed increased days open and days to conception in cows suffering from uterine diseases, such as CE and SCE (Elkjær et al., 2013; Madoz et al., 2013). The decreased number of acute infection cases (scores 3 ) of the endometrium caused by $A$. pyogenes could result in the reduction of acute destruction of the endometrium layer and impairment of future reproductive performance of these cows. Most of the beef cow herds exhibit high pregnancy rate during the breeding season that they are properly managed (Amundson et al., 2006) and uterine contamination can be controlled especially after the resumption of the ovarian cycle (Santos et al., 2009). The current study also showed a decline in the pregnancy rate of beef cows $45.1 \%(37 / 82)$ at 200 days post calving because several possible factors affect the reproductive performance of these cows, such as seasonal breeding, prolonged postpartum acyclicity in suckled beef cows, nutrition, breed and uterine infection. Pregnancy rates in the day 200 after birth was more than at 150 days, the reason for that may be these cows have a longer period to overcome their reproductive problems and more chance to be pregnant. Extended post calving anestrus in suckled beef cows is one of the most common limitations to gaining a calf every year (Miller and Ungerfeld, 2008). Climatic stress, parity, extended suckling, nutritional deficiencies, and management practices were the most common reasons of prolonged calving intervals (Diskin and Kenny, 2016).

Further studies are needed to shed light on the uterine infections in beef cows and its relationship to other factors that cause weakness of the reproductive performance of these cows.

\section{CONCLUSION}

A moderate agreement exists among PMN \%, bacteriological findings, and vaginal discharges, whereas a poor agreement exists between bacterial findings and PMN \%. E. coli, $S$. aureus, and calving assistance (dystocia) were the major factors affecting uterine infection in beef cows. CE and SCE insignificantly affected the reproductive performance of beef cows.

\section{ACKNOWLEDGMENTS}

The study was funded by UPM grant, Serdang, Selangor, Malaysia. Grant number 9441600.

I would like to thank all my colleagues and all the workers in the cow herds to help me complete this study.

\section{Author Contributions}

All authors contributed effectively in this research, N. Salab designed and achieved experiments and wrote the paper; B. Siti khairani performed bacteriological part of the work; M.A.Omar analysed the data; N. Yimer, H. Wabid, and Y. Rosnina supervised the project and revised the manuscript.

\section{REFERENCES}

Amundson, J. L., T. L. Mader, R. J. Rasby and Q. S. Hu. 2006. Environmental effects on pregnancy rate in beef cattle. J. Anim. Sci. 84: 3415-3420.

Barański, W., M. Podhalicz-Dziegielewska, S. Zduńczyk and T. Janowski. 2012. The diagnosis and prevalence of subclinical endometritis in cows evaluated by different cytologic thresholds. Theriogenology. 78: 1939-1947.

Barlund, C. S., T. D. Carruthers, C. L. Waldner and C. W. Palmer. 2008. A comparison of diagnostic techniques for postpartum endometritis in dairy cattle. Theriogenology. 69: 714-723.

Bormann, J. M., L. R. Totir, S. D. Kachman, R. L. Fernando and D. E. Wilson. 2006. Pregnancy rate and first-service conception rate in Angus heifers. J. Anim. Sci. 84: 2022-2025.

Bourke, M., J. N. Mills and A. L. Barnes. 1997. Collection of endometrial cells in the mare. Aust. Vet. J. 75: 755-758.

Cheong, S. H., D. V. Nydam, K. N. Galvão, B. M. Crosier and R. O. Gilbert. 2011. Cow-level and herd-level risk factors for subclinical endometritis in lactating Holstein cows. J. Dairy Sci. 94: 762-770.

Diskin, M. G. and D. A. Kenny. 2016. Managing the reproductive performance of beef cows. Theriogenology. 86: 379-387.

Dubuc, J., T. F. Duffield, K. E. Leslie, J. S. Walton and S. J. LeBlanc. 2010. Risk factors for postpartum uterine diseases in dairy cows. J. Dairy Sci. 93: 5764-5771.

Elkjær, K., R. Labouriau, M. L. Ancker, H. Gustafsson and H. Callesen. 2013. Practical use of a uterine score system for predicting effects on interval from calving to first insemination and nonreturn rate 56 in Danish dairy herds. Vet. J. 198: 644-648.

Ferguson, J. D., D. T. Galligan and N. Thomsen. 1994. Principal descriptors of body condition score in Holstein cows. J. Dairy Sci. 77: 2695-2703.

Gilbert, R. O., S. T. Shin, C. L. Guard, H. N. Erb and M. Frajblat. 2005. Prevalence of endometritis and its effects on reproductive performance of dairy cows. Theriogenology. 64: 1879-1888.

Hammon, D. S., I. M. Evjen, T. R. Dhiman, J. P. Goff and J. L. Walters 2006. Neutrophil function and energy status in Holstein cows with uterine health disorders. Vet. Immunol. Immunopathol. 113: 21-29.

Heuwieser, W., B. A. Tenhagen, M. Tischer, J. Lühr and H. Blum. 2000. Effect of three programmes for the treatment of endometritis on the reproductive performance of a dairy herd. Vet. Rec. 146: 338-341.

Kasimanickam, R., T. F. Duffield, R. A. Foster, C. J. Gartley, K. E. Leslie, J. S. Walton and W. H. Johnson. 2004. Endometrial cytology and ultrasonography for the detection of subclinical endometritis in postpartum dairy cows. Theriogenology. 62: 9-23.

LeBlanc, S. J., T. F. Duffield, K. E. Leslie, K. G. Bateman, G. P. Keefe, J. S. Walton and W. H. Johnson. 2002. Defining and diagnosing postpartum clinical endometritis and its impact on reproductive performance in dairy cows. J. Dairy Sci. 85: 2223-2236. 
Leutert, C., X. von Krueger, J. Plöntzke and W. Heuwieser. 2012. Evaluation of vaginoscopy for the diagnosis of clinical endometritis in dairy cows. J. Dairy Sci. 95: 206-212.

Madoz, L. V., M. J. Giuliodori, M. Jaureguiberry, J. Plöntzke, M. Drillichand and R. L. de la Sota. 2013. The relationship between endometrial cytology during estrous cycle and cutoff points for the diagnosis of subclinical endometritis in grazing dairy cows. J. Dairy Sci. 96: 4333-4339.

McDougall, S., H. Hussein, D. Aberdein, K. Buckle, J. Roche, C. Burke, M. Mitchell and S. Meier. 2011. Relationships between cytology, bacteriology and vaginal discharge scores and reproductive performance in dairy cattle. Theriogenology. 76: $229-240$.

Miller, V. and R. Ungerfeld. 2008. Weekly bull exchange shortens postpartum anestrus in suckled beef cows. Theriogenology. 69: 913-917.

Potter, T. J., J. Guitian, J. Fishwick, P. J. Gordon and I. M. Sheldon. 2010. Risk factors for clinical endometritis in postpartum dairy cattle. Theriogenology. 74: 127-134.

Prunner, I., H. Pothmann, K. Wagener, M. Giuliodori, J. Huber, M. Ehling-Schulz and M. Drillich. 2014a. Dynamics of bacteriologic and cytologic changes in the uterus of postpartum dairy cows. Theriogenology. 82: 1316-1322.

Prunner, I., K. Wagener, H. Pothmann, M. Ehling-Schulz and M. Drillich. 2014b. Risk factors for uterine diseases on small-and medium-sized dairy farms determined by clinical, bacteriological, and cytological examinations. Theriogenology. 82: 857-865.

Rogers, P. L., C. T. Gaskins, K. A. Johnson and M. D. MacNeil. 2004. Evaluating longevity of composite beef females using survival analysis techniques. J. Anim. Sci. 82: 860-866.

Runciman, D. J., G. A. Anderson, J. Malmo and G. M. Davis. 2008. Use of postpartum vaginoscopic (visual vaginal) examination of dairy cows for the diagnosis of endometritis and the association of endrometritis with reduced reproductive performance. Aust. Vet. J. 86: 205-213.

Santos, N. R., G. C. Lamb, D. R. Brown and R. O. Gilbert. 2009.
Postpartum endometrial cytology in beef cows. Theriogenology. 71: 739-745.

Santos, T. M. A., R. O. Gilbert and R. C. Bicalho. 2011. Metagenomic analysis of the uterine bacterial microbiota in healthy and metritic postpartum dairy cows. J. Dairy Sci. 94: 291-302.

Sens, A. and W. Heuwieser. 2013. Presence of Escherichia coli, Trueperella pyogenes, a-hemolytic streptococci, and coagulase-negative staphylococci and prevalence of subclinical endometritis. J. Dairy Sci. 96: 6347-6354.

Sheldon, I. M., G. S. Lewis, S. LeBlanc and R. O. Gilbert. 2006. Defining postpartum uterine disease in cattle. Theriogenology. 65: 1516-1530.

Studer, E. and D. A. Morrow. 1978. Postpartum evaluation of bovine reproductive potential: Comparison of findings from genital tract examination per rectum, uterine culture, and endometrial biopsy. J. Am. Vet. Med. Assoc. 172: 489-494.

Werner, A., V. Suthar, J. Plöntzke and W. Heuwieser. 2012. Relationship between bacteriological findings in the second and fourth weeks postpartum and uterine infection in dairy cows considering bacteriological results. J. Dairy Sci. 95: 7105-7114.

Westermann, S., M. Drillich, T. B. Kaufmann, L. V. Madoz and W. Heuwieser. 2010. A clinical approach to determine false positive findings of clinical endometritis by vaginoscopy by the use of uterine bacteriology and cytology in dairy cows. Theriogenology. 74: 1248-1255

Wettemann, R. P., C. A. Lents, N. H. Ciccioli, F. J. White and I. Rubio. 2003. Nutritional-and suckling-mediated anovulation in beef cows. J. Anim. Sci. 81: 48-59.

Williams, E. J., D. P. Fischer, D. U. Pfeiffer, G. C. W. England, D. E. Noakes, H. Dobson and I. M. Sheldon. 2005. Clinical evaluation of postpartum vaginal mucus reflects uterine bacterial infection and the immune response in cattle. Theriogenology. 63: $102-117$

Zobel, R. 2013. Endometritis in Simmental cows: Incidence, causes, and therapy options. Turk. J. Vet. Anim. Sci. 37: 134-140. 